\title{
Compositional and textural properties of goat's milk cheese prepared using dahi (yogurt) as the starter culture
}

\section{Composição e propriedades de textura de queijo de leite de cabra preparado usando dahi (iogurte) como starter}

\author{
Umair Shabbir $^{1 *}$ (D), Nuzhat Huma ${ }^{1}$, Ahsan Javed ${ }^{2}$ \\ ${ }^{1}$ University of Agriculture, National Institute of Food Science and Technology, Faisalabad - Pakistan \\ ${ }^{2}$ Government College University, Institute of Home and Food Sciences, Faisalabad - Pakistan
}

${ }^{*}$ Corresponding Author: Umair Shabbir, University of Agriculture, National Institute of Food Science and Technology, +38000, Faisalabad - Pakistan, e-mail: umair336@gmail.com

Cite as: Shabbir, U., Huma, N., \& Javed, A. (2019). Compositional and textural properties of goat's milk cheese prepared using dahi (yogurt) as the starter culture. Brazilian Journal of Food Technology, 22, e2018289. https://doi.org/10.1590/1981-6723.28918

\begin{abstract}
This study aimed to develop goat's milk cheese to conserve the major milk constituents. Household dahi (yoghurt) is an inexpensive source of starter cultures that contains several types of microorganism of which most are thermophilic in nature and can be used in the production of goat's milk cheese. Different concentrations of dahi $(0.5 \%, 1.0 \%, 1.5 \%, 2.0 \%$ and $2.5 \%)$ were used to prepare the cheeses following the standard procedure for cheese manufacturing. The cheeses were analysed for their physicochemical, textural and organoleptic parameters. The highest yield was recorded for $\mathrm{T}_{1.0 \%}(17.33 \%)$ and the lowest for $\mathrm{T}_{2.5 \%}(15.58 \%)$. Significant $(p<0.05)$ differences were found for the $\mathrm{pH}$, acidity and moisture content of the different goat's milk cheese samples. The moisture content was highest in $T_{0.5 \%}$ (59.30) and lowest in $T_{2.5 \%}$ (52.20). The texture profile was significant $(p<0.05)$ for firmness, adhesiveness, gumminess and chewiness between the treatments. The sensory scores indicated that $T_{1.0 \%}$ was preferred by the panellists, followed by $T_{1.5 \%}$ and then the other treatments. It was concluded that goat's milk cheese could be prepared with good quality characteristics using $1 \%$ dahi as the starter culture.
\end{abstract}

Keywords: Cheese; Concentration; Inexpensive; Milk; Texture profile; Organoleptic.

\section{Resumo}

Este estudo visou desenvolver queijo de leite de cabra para preservar os principais constituintes do leite. Dahi (iogurte) feito em casa é uma fonte barata de culturas do tipo starter que contém vários tipos de microrganismos, a maioria dos quais são termofílicos e podem ser usados para produzir queijo de leite de cabra. Concentrações diferentes de dahi $(0,5 \%, 1,0 \%, 2,0 \%$ e $2,5 \%)$ foram usadas para preparar os queijos, seguindo o procedimento padrão para a fabricação de queijo. Os queijos foram analisados quanto a parâmetros físico-químicos, texturais e organolépticos. O rendimento maior foi registrado para $T_{1,0 \%}$ (17,33\%) e o menor para $T_{2,5 \%}$ (15,58\%). Diferenças significativas $(p<0,05)$ foram encontradas entre as diferentes amostras de queijo de leite de cabra para o $\mathrm{pH}$, a acidez e a umidade. A umidade foi mais alta para $\mathrm{T}_{0,5 \%}(59,30)$ e mais baixa para $\mathrm{T}_{2,5 \%}(52,20)$. O perfil de textura foi 
significativo $(p<0,05)$ entre os tratamentos para firmeza, adesividade, gomosidade e mastigação. As notas sensoriais indicaram $\mathrm{T}_{1,0 \%}$ como sendo a amostra preferida pelos provadores, seguida por $\mathrm{T}_{1,5 \%}$ e os outros tratamentos. Foi concluído que queijo de leite de cabra pode ser preparado com boas características de qualidade usando-se $1 \%$ de dahi como a cultura tipo starter.

Palavras-chave: Queijo; Concentração; Baixo custo; Leite; Perfil de textura; Organoléptico.

\section{Introduction}

The livestock and agricultural sector has a great impact on the economy of countries, by combating the nutritional needs of the people. The agricultural economy of various countries, especially France, Spain and Greece, is highly dependent on the goat population. The goat population and goat's milk production increased $69 \%$ and 86\%, respectively, in the world from 1991 to 2014 (Food and Agriculture Organization of the United Nations, 2015). Considering the goat population, in 2014 there were 4.25 million goat heads in Greece; 2.70 million in Spain and 1.27 million in France In the same year, goat's milk production was very high in France, Spain and Greece, as high as 604, 447 and 351 million liters, respectively (European Statistics, 2016).

Goat's milk is in $3^{\text {rd }}$ position in the total milk production (0.89 MT/annum), with 72.2 million heads, ranking first in the total animal population in Pakistan (2017). People living in rural areas the world over consider the goat as a source of milk and meat. Many scientists called it the poor man's cow due to economical production and ease in rearing (Leitner et al., 2007). Almost $2 \%$ of the total milk production per year is produced by goats, which plays a very significant role in the health and financial well-being of mankind. Goat's milk can easily be used by people who are hypersensitive to cow's milk (Park, 2007).

Various types of goat's milk products such as curd, frozen yoghurt, milk powder, butter, skimmed milk, enriched milk and fermented milk products are available on the market (Park, 2007). Besides all these products, goat's milk cheese is a very rare and nutritious type of cheese, which is soft in texture and white in colour, palatable to the taste and enriched with vitamins (Ayar et al., 2009).

Cheese is a coagulated and concentrated milk product that has a wide range of flavours, textures, forms and varieties. The starter cultures required for cheese production are very expensive and not easily available in Pakistan. Dahi (yoghurt), which is a local fermented product can easily be prepared at home and is also available on the local market rather than imported cultures. Dahi contains several thermophilic bacteria but the dominant forms are Streptococcus thermophilus and Lactobacillus ssp. (Lb. delbruccki subsp. bulgaricus). There is little knowledge about goat's milk cheese manufacturing in Pakistan. The goats are mainly reared by small farmers or small land holders in Pakistan who use the goats milk for their own consumption, very little being commercialized. So, the conservation of the milk in the form of cheese could be an option for small farmers. The present study aimed to use good quality homemade dahi as the starter culture for the production of goat's milk cheese, representing a good initiative on the scientific side of industry. This small effort will definitely increase the economy of dairy industry and help poor farmers to establish their own small-scale businesses.

\section{Material and methods}

\subsection{The search for the raw material}

Goat's and buffalos were obtained in Faisalabad-Pakistan. Goat's milk cheese was prepared using dahi as the starter culture at concentrations of $0.5 \%\left(\mathrm{~T}_{0.5 \%}\right), 1.0 \%\left(\mathrm{~T}_{1.0 \%}\right), 1.5 \%\left(\mathrm{~T}_{1.5 \%}\right), 2 \%\left(\mathrm{~T}_{2.0 \%}\right)$ and $2.5 \%\left(\mathrm{~T}_{2.5 \%}\right)$ for cheese production, and the enzyme coagulant rennet (Chr. Hansen) for curd formation was obtained on the local market. The trials were carried out using $5 \pm 0.05$ liters of goat's milk. 


\subsection{Preparation of dahi}

Dahi was prepared from skimmed buffalo milk; the milk was first pasteurized at $72{ }^{\circ} \mathrm{C}$ for 15 seconds, cooled to $42{ }^{\circ} \mathrm{C}, 2 \%$ already prepared $d a h i$ added and incubated for 4 hours. The prepared dahi was used as the starter culture.

\subsection{Physicochemical analyses of milk}

The acidity, total solids, ash and protein contents of the milk samples were determined according to Association of Official Analytical Chemists (2012), pH value according to Ong et al. (2007) and the fat content according to Marshal (1993).

\subsection{Cheese preparation}

Figure 1 shows the method of cheese manufacturing.

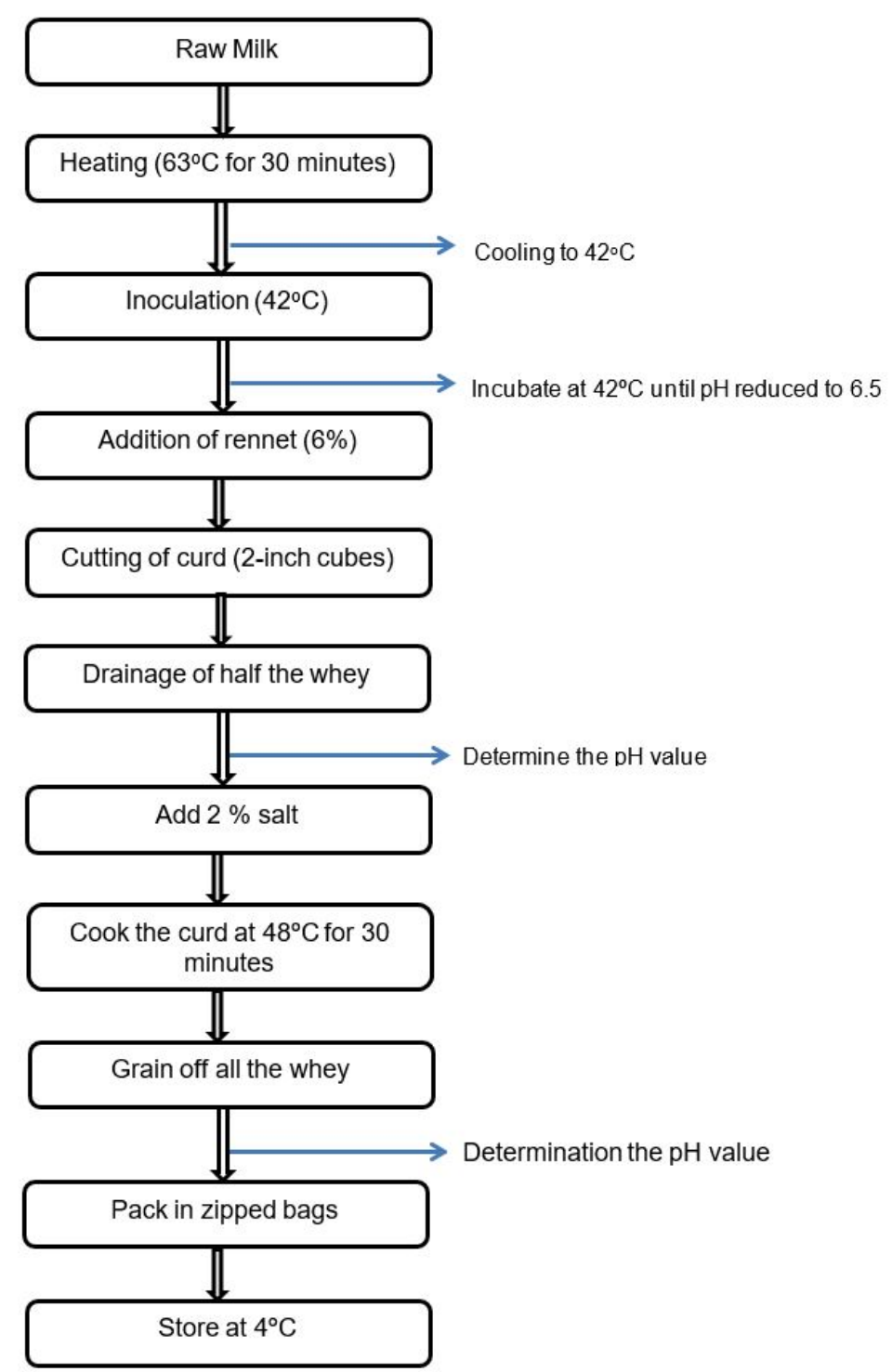

Figure 1. Goat's milk cheese production. 


\subsection{Cheese yield}

After drainage the cheese yield was calculated according to the Equation 1 given below:

$$
\text { Yield }(\%)=\frac{\text { Cheese weight }(\mathrm{kg})}{\text { Milk weight }(\mathrm{kg})} \times 100
$$

\subsection{Physicochemical analyses of the cheese}

The acidity, $\mathrm{pH}$, fat and protein contents of the cheese samples were determined using the same methods given for the physicochemical analyses of the milk, and the cheese texture was characterised using the Texture Profile Analyzer as described by Guinee et al. (2007). The method of Clark et al. (2009) was used for the sensory evaluation of the cheeses.

\subsection{Organoleptic evaluation}

Small cubes $(2 \mathrm{~cm})$ of cheese samples were placed on white plates at ambient $\left(25 \pm 2{ }^{\circ} \mathrm{C}\right)$ and presented to the panellists. Five trained panellists, all highly familiar with cheese, evaluated the cheese samples. The sensory evaluation was recorded using a 9-point hedonic scale.

\subsection{Statistical analysis}

All the analyses were carried out with 6 replicates and the results subjected to the statistical parameters according to CRD (Steel et al., 1997).

\section{Results and discussion}

\subsection{Chemical analyses of the milk}

The results obtained for the goat's milk used to manufacture the cheese were: $\mathrm{pH}(6.61 \pm 0.04)$, acidity $(0.17 \pm 0.01)$, fat $(3.8 \% \pm 0.07 \%)$, protein $(3.3 \% \pm 0.11 \%)$, ash $(0.70 \% \pm 0.01 \%)$ and total solids $(12.21 \% \pm 0.14 \%)$. The fat ( $3 \%$ to $5 \%)$, protein $(2.4 \%$ to $4.1 \%)$, total solids $(6.61 \%$ to $6.85 \%)$ and ash $(0.69 \%$ to $0.74 \%$ ) contents of the goat's milk used here were comparable to those of Guo et al. (2001). The total solids showed variations that might have been due to changes in the fat, protein, lactose and mineral contents of the milk. Seasonal variations and changes in the genotypes of the animals can also lead to variations in the goat's milk composition.

\subsection{Yield and physicochemical composition of cheese}

The different concentrations of dahi added as the starter culture had a significant effect on the cheese yield. $\mathrm{T}_{1.0 \%}$ provided the highest percent yield $(17.33 \pm 0.61)$. A lower cheese yield was found with increasing culture concentration, which may have been due to the development of greater acidity, creating unfavourable conditions for the microbes and enzymes to work efficiently and expelling more whey. Hamad \& Ismail (2012) reported a goat's milk cheese yield of between $17.13 \%$ and $17.47 \%$, which is comparable to that obtained in the current study.

Table 1 shows the results obtained for the physicochemical analyses of the goat's milk cheese. With respect to the different culture concentrations, significant differences $(p<0.05)$ were detected for $\mathrm{pH}$ and acidity, and the moisture and fat contents and non-significant differences for the protein content. The $\mathrm{pH}$ values were between $5.74 \pm 0.25$ and $5.00 \pm 0.24$ and the lactic acid concentration between $0.40 \% \pm 0.01 \%$ and $0.58 \% \pm 0.02 \%$. The increase in lactic acid concentration and decrease in the $\mathrm{pH}$ value were due to the increasing concentrations of $d a h i$ culture added to the cheese, which promoted acidity. The fat content was 
between $16.14 \% \pm 0.74 \%$ and $18.34 \% \pm 0.90 \%$. Hayaloglu et al. (2013) prepared goat's milk cheese using starter free, mesophilic and thermophilic cultures and obtained fat contents between $16.82 \%$ and $17.04 \%$, in agreement with the current studies. The protein content of the cheese samples was between $16.21 \% \pm 01.41 \%$ and $17.61 \% \pm 0.84 \%$. Santos et al. (2016) reported a protein content of between $15.45 \% \pm 4.32 \%$ and $16.54 \%$ $\pm 4.75 \%$ for fresh cream goat's milk cheese, values in agreement with those obtained in the present study.

The moisture content varied from $52.20 \% \pm 1.40 \%$ to $59.30 \% \pm 1.49 \%$, the difference in moisture content being due to acid development in the cheese samples, the acidity working as a moisture expeller from the cheese. Thus, more development of acid more will be the moisture loss in cheese. The moisture content of goat's milk cheese reported by Kondyli et al. (2016) was from $54.51 \%$ to $57.3 \%$, results comparable to those of the current study.

Table 1. Physicochemical analyses of the goat's milk cheese.

\begin{tabular}{cccccc}
\hline Treatments & $\begin{array}{c}\text { Moisture } \\
(\mathbf{\%})\end{array}$ & $\begin{array}{c}\text { Acidity } \\
(\mathbf{\%})\end{array}$ & pH & $\begin{array}{c}\text { Fat } \\
(\%)\end{array}$ & $\begin{array}{c}\text { Protein } \\
(\%)\end{array}$ \\
\hline $\mathrm{T}_{0.5 \%}$ & $59.30 \pm 1.49^{\mathrm{A}}$ & $0.40 \pm 0.01^{\mathrm{D}}$ & $5.74 \pm 0.25^{\mathrm{A}}$ & $18.34 \pm 0.90^{\mathrm{A}}$ & $17.61 \pm 0.84^{\mathrm{A}}$ \\
$\mathrm{T}_{1.0 \%}$ & $56.69 \pm 0.72^{\mathrm{B}}$ & $0.45 \pm 0.02^{\mathrm{C}}$ & $5.60 \pm 0.24^{\mathrm{AB}}$ & $18.02 \pm 0.90^{\mathrm{AB}}$ & $17.48 \pm 0.80^{\mathrm{A}}$ \\
$\mathrm{T}_{1.5 \%}$ & $55.25 \pm 1.27^{\mathrm{BC}}$ & $0.49 \pm 0.02^{\mathrm{B}}$ & $5.35 \pm 0.24^{\mathrm{ABC}}$ & $17.53 \pm 1.15^{\mathrm{ABC}}$ & $17.09 \pm 0.88^{\mathrm{A}}$ \\
$\mathrm{T}_{2.0 \%}$ & $53.80 \pm 0.93^{\mathrm{CD}}$ & $0.52 \pm 0.02^{\mathrm{B}}$ & $5.20 \pm 0.23^{\mathrm{BC}}$ & $16.56 \pm 0.82^{\mathrm{BC}}$ & $16.62 \pm 0.80^{\mathrm{A}}$ \\
$\mathrm{T}_{2.5 \%}$ & $52.20 \pm 1.40^{\mathrm{D}}$ & $0.58 \pm 0.02^{\mathrm{A}}$ & $5.00 \pm 0.24^{\mathrm{C}}$ & $16.14 \pm 0.74^{\mathrm{C}}$ & $16.21 \pm 1.41^{\mathrm{A}}$ \\
\hline
\end{tabular}

The superscripts A-D indicate means that significantly differ at $p<0.05$ within the same parameter.

\subsection{Texture profile analysis}

Table 2 shows the texture parameters determined for the goat's milk cheese. It can be seen that the values obtained for firmness $(\mathrm{N})$, gumminess $(\mathrm{N})$, chewiness $(\mathrm{mJ})$ and elasticity $(\mathrm{mm})$ in the cheese sample showed a trend to increase with increasing culture concentration, whilst the values obtained for adhesiveness $(\mathrm{mJ})$ and cohesiveness (\%) decreased with increasing culture concentration. The addition of different concentrations of starter culture significantly $(p<0.05)$ affected the firmness, adhesiveness, gumminess and cohesiveness of the cheeses, while non-significant changes in elasticity were observed. The highest values for firmness $(\mathrm{N})$ were observed for $\mathrm{T}_{2.5 \%}(3.00 \pm 0.13)$ and the lowest values $(2.10 \pm 0.09)$ for $\mathrm{T}_{0.5 \%}$. Adhesiveness $(\mathrm{mJ})$ showed the maximum value $(0.46 \pm 0.02)$ for $\mathrm{T}_{0.5 \%}$ and minimum value $(0.29 \pm 0.04)$ for $\mathrm{T}_{2.5 \%}$. The highest value for cohesiveness (\%) $(0.46 \pm 0.02)$ was found for $\mathrm{T}_{0.5 \%}$ and the lowest $(0.32 \pm 0.02)$ for $\mathrm{T}_{2.5 \%}$. Maximum values for elasticity $(\mathrm{mm})(3.39 \pm 0.03)$ were observed for $\mathrm{T}_{2.5 \%}$ and the lowest $(2.99 \pm 0.13)$ for $\mathrm{T}_{0.5 \%}$, whilst the values for gumminess $(\mathrm{N})$ and chewiness $(\mathrm{mJ})$ were also higher in $\mathrm{T}_{2.5 \%}$ and lower in $\mathrm{T}_{0.5 \%}$.

According to Kumar et al. (2014), the more elastic the cheese, the greater its resistance to breakage and therefore the greater the cohesiveness, the values reported in this study for the elasticity and cohesiveness of the cheeses agreeing with this information. The adhesiveness and cohesiveness decreased with increasing culture concentration due to the decrease in moisture concentration.

Table 2. Values of the texture profile analyses.

\begin{tabular}{cccccc}
\hline Parameters & $\mathbf{T}_{\mathbf{0 . 5}}$ & $\mathbf{T}_{\mathbf{1 . 0}}$ & $\mathbf{T}_{\mathbf{1 . 5}}$ & $\mathbf{T}_{\mathbf{2 . 0}}$ & $\mathbf{T}_{\mathbf{2 . 5}}$ \\
\hline Firmness (N) & $2.10 \pm 0.09^{\mathrm{C}}$ & $2.22 \pm 0.9^{\mathrm{C}}$ & $2.64 \pm 0.11^{\mathrm{B}}$ & $2.94 \pm 1.28^{\mathrm{A}}$ & $3.00 \pm 0.13^{\mathrm{A}}$ \\
Adhesiveness (mJ) & $0.46 \pm 0.02^{\mathrm{A}}$ & $0.40 \pm 0.02^{\mathrm{B}}$ & $0.36 \pm 0.03^{\mathrm{C}}$ & $0.33 \pm 0.01^{\mathrm{C}}$ & $0.29 \pm 0.04^{\mathrm{D}}$ \\
Cohesiveness (\%) & $0.46 \pm 0.02^{\mathrm{A}}$ & $0.45 \pm 0.02^{\mathrm{A}}$ & $0.40 \pm 0.18^{\mathrm{B}}$ & $0.36 \pm 0.01^{\mathrm{BC}}$ & $0.32 \pm 0.02^{\mathrm{C}}$ \\
Elasticity (mm) & $3.39 \pm 0.03^{\mathrm{A}}$ & $3.30 \pm 0.14^{\mathrm{A}}$ & $3.20 \pm 0.14^{\mathrm{AB}}$ & $3.15 \pm 0.14^{\mathrm{AB}}$ & $2.99 \pm 0.13^{\mathrm{B}}$ \\
Gumminess (N) & $0.89 \pm 0.02^{\mathrm{C}}$ & $0.94 \pm 0.01^{\mathrm{BC}}$ & $0.98 \pm 0.01^{\mathrm{B}}$ & $1.05 \pm 0.01^{\mathrm{AB}}$ & $1.08 \pm 0.21^{\mathrm{A}}$ \\
Chewiness (mJ) & $2.94 \pm 0.13^{\mathrm{D}}$ & $2.63 \pm 0.38^{\mathrm{C}}$ & $3.00 \pm 0.13^{\mathrm{B}}$ & $3.23 \pm 0.14^{\mathrm{A}}$ & $3.25 \pm 0.14^{\mathrm{A}}$ \\
\hline
\end{tabular}

The superscripts A-D indicate means that significantly differ at $p<0.05$ within the same parameter. 


\subsection{Organoleptic evaluation}

The maximum sensory scores were awarded to $\mathrm{T}_{1.0 \%}$ (shown in Figure 2), being 6.39 for colour, 6.38 for flavour, 7.24 for taste, 6.38 for texture and 7.27 for overall acceptance, followed by $\mathrm{T}_{1.5 \%}$ with 6.12 for colour, 6.44 for flavour, 6.99 for taste, 5.9 for texture and 7.05 for overall acceptability. Hence, the $\mathrm{T}_{1.0 \%}$ samples were preferred by the panellists, followed by $\mathrm{T}_{1.5 \%}$.
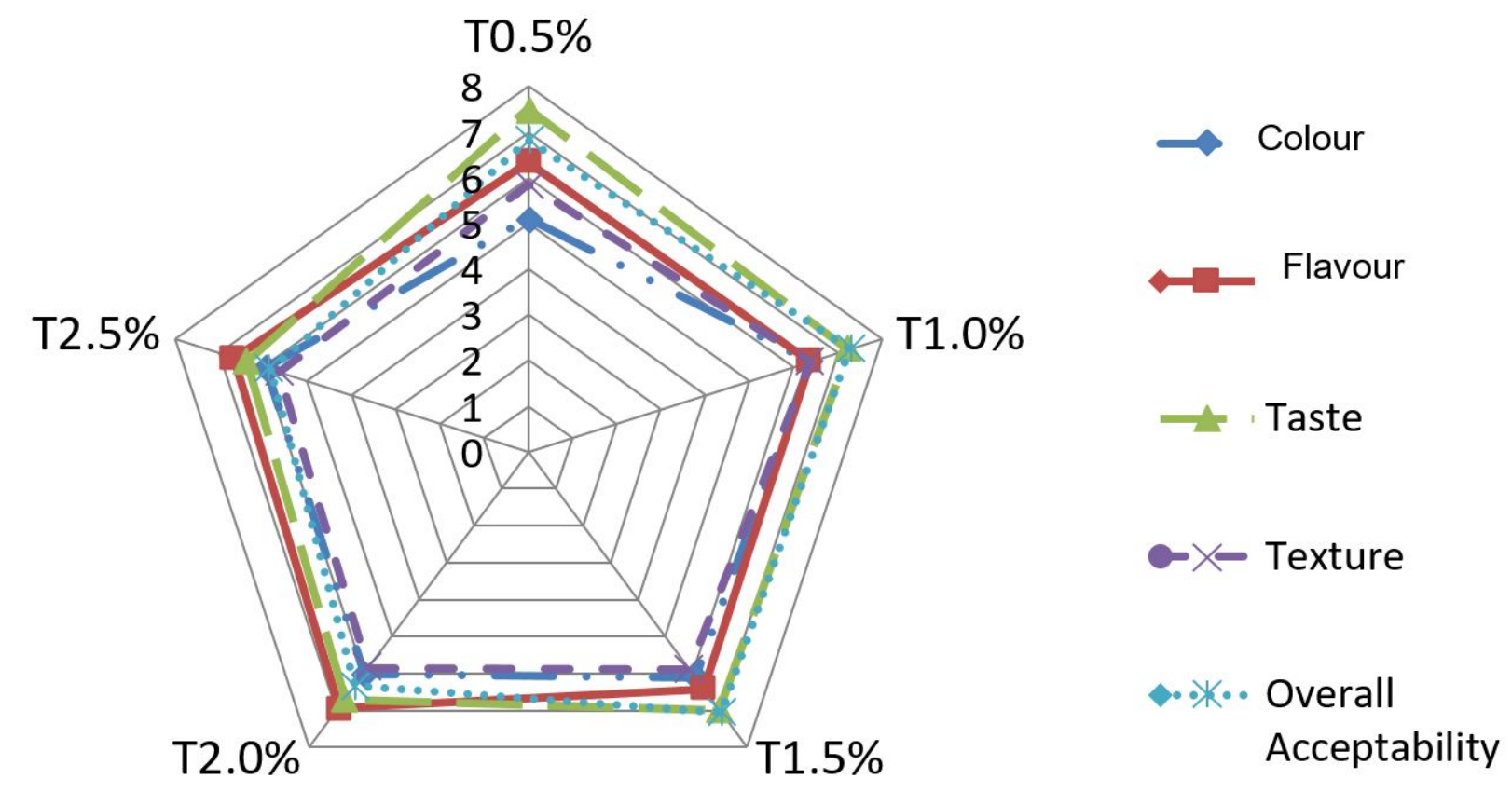

Figure 2. Sensory scores for goat's milk cheese.

\section{Conclusion}

It was concluded that dahi could be used as the starter culture in the production of goat's milk cheese, a concentration of $1 \%$ being the most suitable. More work is required to optimize the conditions for cheese making. The use of dahi as the starter culture will help small manufacturers since it has a negligible price, and the cheeses can be prepared economically by poor people.

\section{Acknowledgements}

The authors are grateful to the Dairy Technology Laboratory and Nutrition Assessment Laboratory of the National Institute of Food Science and Technology, University of Agriculture Faisalabad, Pakistan for their assistance.

\section{References}

Association of Official Analytical Chemists - AOAC. (2012). Official method of analysis (19th ed., Vol. 1). Washington: AOAC. Ayar, A., Sert, D., \& Akin, N. (2009). The trace metal levels in milk and dairy products consumed in middle Anatolia-Turkey. Environmental Modeling and Assessment, 152(1-4), 1-12. http://dx.doi.org/10.1007/s10661-008-0291-9

Clark, S., Costello, M., Drake, M. A., \& Bodyfelt, F. (2009). The sensory evaluation of dairy products (2nd ed.). New York: Springer. http://dx.doi.org/10.1007/978-0-387-77408-4.

European Statistics - EUROSTAT. (2016). Retrieved in 2017, September 1, from http://ec.europa.eu/eurostat Food and Agriculture Organization of the United Nations - FAOSTAT. (2015). Retrieved in 2018, July 5, from http://faostat.fao.org 
Guinee, T. P., Mulholland, E. O., Kelly, J., \& Callaghan, D. J. O. (2007). Effect of protein-to-fat ratio of milk on the composition, manufacturing efficiency and yield of cheddar cheese. Journal of Dairy Science, 90(1), 110-123. PMid:17183080. http://dx.doi.org/10.3168/jds.S0022-0302(07)72613-9

Guo, M. R., Dixon, P. H., Park, Y. W., Gilmore, J. A., \& Kindstedt, P. S. (2001). Seasonal changes in the chemical composition of commingled goat milk. Journal of Dairy Science, 84, 79-83. http://dx.doi.org/10.3168/jds.S0022-0302(01)70201-9

Hamad, M. N., \& Ismail, M. M. (2012). Quality of soft cheese made with goat's milk as affected with the addition of certain essences. Journal of Animal and Veterinary Advances, 2(2), 121-127.

Hayaloglu, A. A., Tolu, C., \& Yasar, K. (2013). Influence of goat breeds and starter culture systems on gross composition and proteolysis in Gokceada goat cheese during ripening. Small Ruminant Research, 113(1), 231-238. http://dx.doi.org/10.1016/j.smallrumres.2013.03.001

Kondyli, E., Pappa, E. C., \& Svarnas, C. (2016). Ripening changes of the chemical composition, proteolysis, volatile fraction and organoleptic characteristics of a white-brined goat milk cheese. Small Ruminant Research, 145, 1-6. http://dx.doi.org/10.1016/j.smallrumres.2016.10.022

Kumar, S., Kanawjia, S. K., Kumar, S., \& Khatkar, S. (2014). Effect of rate of addition of starter culture on textural characteristics of buffalo milk Feta type cheese during ripening. Journal of Food Science and Technology, 51(4), 800-804. PMid:24741179. http://dx.doi.org/10.1007/s13197-011-0565-z

Leitner, G., Merin, J., Lavi, Y., Egber, A., \& Silanikove, N. (2007). Aetiology of intramammary infection and its effect on milk composition in goat flocks. The Journal of Dairy Research, 74(2), 186-193. PMid:17227594. http://dx.doi.org/10.1017/S0022029906002299

Marshal, R. T. (1993). Standard methods for examination of dairy products (16th ed.). Washington: APHA.

Ong, L., Henriksson, A., \& Shah, N. P. (2007). Proteolytic pattern and organic acid profiles of probiotic Cheddar cheese as influenced by probiotic strains of Lactobacillus acidophilus, Lb. paracasei, Lb. casei or Bifidobacterium sp. International Dairy Journal, 17(1), 67-78. http://dx.doi.org/10.1016/j.idairyj.2005.12.009

Pakistan. Ministry of Finance. (2017). Economic survey of Pakistan. Retrieved in 2018, September 5, from http://www.finance.gov.pk/survey_1415.html

Park, Y. W. (2007). Rheological characteristics of goat and sheep milk. Small Ruminant Research, 68(1-2), 73-87. http://dx.doi.org/10.1016/j.smallrumres.2006.09.015

Santos, T. D., Gonçalves, B. H. R., \& Carvalho, S. A. (2016). Physical, chemical and sensory characteristics of cream goat cheese produced with Saanen and Alpine milk. International Journal of Engineering Science, 2, 102-111.

Steel, R., Torrie, J. H., \& Dickey, D. (1997). Principles and procedures of statistics: A biometrical approach (3rd ed.). New York: McGraw Hill Book. 